\title{
Role of Demographic in Gratitude to Reduce Job Related Sress Among School Teachers
}

\author{
Muhammad Ali Talha \\ Ph.D Scholar \\ School of Education Sciences, Nanjing Normal University, China \\ Professor Xuehong Qi \\ School of Education Sciences, Nanjing Normal University, China \\ Muhammad Rizwan \\ Ph.D Scholar \\ School of Education Sciences, Nanjing Normal University, China
}

\begin{abstract}
Gratitude is one of the robust dimensions of positive psychology that strengthens a person's character. Gratitude can motivate individuals to have a firm belief in God and to help in coping with stress and transmit a supportive social connection in society. The current study aims to determine the role of demographics variables in gratitude and how gratitude plays a role in reducing stress of school teachers. It was a quantitative study; simple random sampling was used to collect the data. The sample of the study comprised 200 participants of school teachers from Sialkot and Multan district. Three instruments were used to collect the data; demographic sheet, the gratitude questionnaire, and the job stress scale, respectively. Data were analyzed through SPSS 2.1v. Descriptive analysis and chi-square analysis were used on the gathered data. Our findings revealed that gratitude has a significant association with demographics. The majority of the sample was Muslims (97.5\%), and 36.1\% of participants were suffering in job-related stress, and the situation was alarming $20.9 \%$ of the respondents need to psycho-therapeutic treatment. Job-status had a significant association with gratitude. $67.1 \%$ of the participants were highly educated (Master). The education reforms sector in Pakistan should introduce the Psychotherapeutic session for the counseling of the teachers. A screening kit will be provided in schools as lack of gratitude leads to stress. Govt. of Pakistan started the initiative program 'Reading of Quran with translation' that brings an optimistic change in teachers' thought-changing pattern.
\end{abstract}

Keywords: Job related stress, Gratitude, Positive Psychology, Chi- square

DOI: $10.7176 /$ RHSS/10-22-10

Publication date: November $30^{\text {th }} 2020$

\section{Introduction}

Gratitude is a fundamental element or a central feature of any religion such as Islam, Hinduism, Christianity, Buddhism, and Judaism for centuries (Armenta et al. 2016). While it is the cornerstone of the philosophy, gratitude was not on the Psychology list, but now researchers have investigated the practice of gratitude and its effects on well-being. But a rapid scientific development potential was created by the previous low knowledge base (McCullough et al., 2002). Since the researcher performed psychological experiments before modern psychology and philosophy and theology, the approach to psychological events and circumstances was philosophical and theological. Researchers said that gratitude is a way of thanking people, Heaven, and nature when we look at the philosophers and theologians who dealt with the psychological perspective (Emmons \& McCullough, 2003). Gratitude is described as a feeling or a character trait in the literature of psychology. Gratitude is compiled based on cognitive and emotional reactions that occur when a person thinks about their existence. Gratitude refers to as secret to life and the most special force in the cosmos. Gratitude is related to positive emotions that help out an individual in making his psychological and intellectual resources. If any individual is interested in building his positive emotions, gratitude plays a vital role in encouraging him to engage in healthy habits that contribute to self-improvement (Diener, 2000).

Stress is a part of our life, and it affects our behavior in different ways, which directly links with our motivation, performance, and goals. When we talk about stress, "it is an unpleasant state of emotions directly chained with frustration, emotional exhaustion and anxiety”(Kyriacou, 2001).

On the other hand, cognitive components increase the sense of life satisfaction (Diener, Suh, Lucas, \& Smith, 1999). As when we look upon different cultures, we come to know that all those who have higher gratitude in their lives and have a massive number of positive outcomes across different domains. It includes their physical and mental health, their relationship with the society, and the personal and third one is the stress at the workplace (Diener et al., 1999). When we trace out individual life span, we came to know that gratitude has been shown remarkably well in their quality of life and increase their social circle and behavior (De Neve, Diener, Tay, 
\&Xuereb, 2013).

Researches explained that gratitude helps individual behavior and decreases the risk of heart problems, and increases life satisfaction (Boehm, Peterson, Kivimaki, \&Kubzansky, 2011; De Neve et al., 2013; Diener\& Chan, 2011). Besides, other research also supports the idea that gratitude plays a vital role in making life successful in different domains, especially theses vibes, direct from positive emotions (Lyubomirsky et al., 2013). When we look at happy individuals, we came to know that their happiness lies behind gratitude.

To enhance the cognitive abilities of an individual, social circle, and psychological and emotional state, whether they are distant from one other but positive emotions of a person can hold these qualities for a long term to foster the growth of individual resources (Fredrickson, 2013). Gratitude can increase the domain of positive emotions, such as joy, happiness, interest. Which directly affects the lifestyle of an individual and boost up the temperament, creativity, and resilience. All these factors play their role in personal as well as social growth. Increase the copping abilities, creative abilities, and foremost, portray a positive image of self and others (Jacobs Bao\&Lyubomirsky, 2012; Lyubomirsky et al., 2005).

When we talk about Pakistan, job stress regarding the education field and teachers has been at the top and kept increasing at a high level that directly affects the quality of teaching and grooming of children. There is an essential question of whether gratitude can be useful to reduce job stress beyond other positive emotions(Schwartz, Tiamiyu, \& Dwyer, 2007). For that, a study was conducted on nurses who work in a hospital burn unit where they face a lot of stress compared to other hospital units. In that research, participants were administered with Hope Scale, whether it can reduce the job stress. Study results show that nurses with high positive hope can manage their work correctly and accurately and report lower job stress than others (Snyder, 1996). Nowadays, many people face problems in their workplace, but up of the hill is stress.

According to Waseem and Iqbal (2012), they successfully found that five primary drives directly affect the job of employ and disturb the relationship with others at the workplace. (Sauter, Murphy, \&Hurrell, 1992), performance pressure (Scott, 1966), workload (Wilkes, Beale, Hall, Rees, Watts, \&Denne, 1998) and homework interface (Alexandros-Stamatios, 2003). According to Sauter (1992), if someone has clashed with their colleagues at their workplace, it will introduce stress in the organization. If we apply to much load on our employees, it will lead to discomfort, which ends with stress and negative progress. Wilkes (1998) stress is directly related to workload; when an individual is not in the work position automatically, stress will increase in his body, and he will feel pressure at their workplace.

Scanders (1983) and Gaillard and Steyvers (1989) said that when we see in an organization when the stress level of an individual is at the top at the bottom, it will have a strong relationship with the performance of employ. In the end, there is a homework interface. It comes into play when an individual's personal life starts overlapping his workplace (Alexandros-Stamatios, 2003). When an individual has stress at home, it will alternatively show some effects of that stress on the workplace. When he has stress at work, it will create a tense environment at home, so stress at home and work have an inverse relationship with stress. Rehman, Irum, Tahir, Ijaz, Noor, and Salma (2012) their primary focus on private colleges and the job stress which faces employees of private institutes.

There are two dimensions of job stress: the workload on employees, that they have to be done in a particular time limit, and the other is the physical environment. The result of their study showed that a low level of physical environment leads to job stress. Mansoor, Fida, Nasir, and Ahmad (2011) work a lot in the Pakistan telecommunication sector on job stress with job satisfaction on employment. In that particular research, they selected 134 employs in which they measured job stress in three ways, which focus on the physical environment of employ, a conflict which has faced by employ wt the workplace, and the third one is the role of conflict. Their result shows that job stress has a negative relationship with job satisfaction. While taking views of different employees, they face more job stress and difficulties when they undergo a high level of exercise, which demands constant energy and time.

According to Hans Selye (1975), when an individual is suffering in stress and unable to cope with, which directly damages the strength of natural Killer cells, which work against stress like cytotoxicity that directly affects human responses against full stress events (Cohen et al., 2001; Dhabhar and McEwan, 1997, 2001; Kiecolt-Glaser et al., 1996).

Recently, as we know, the level of stress has been increasing day by day among teachers in Pakistan. We try our level best to find out job stress among teachers, whether they are also facing the same level of job stress related problems that cause stress. Moreover, there is currently no study that examines gratitude, which will affect job stress among teachers. The main objective of this research is to highlight the issues regarding job stress among school teachers in the Narowal region. As we know, school teachers have been under a lot of stress compared to other teachers, As we know, school teachers have been under a lot of stress compared to other teachers, and they encounter more discomfort than others. This stress has detrimental effects on both their physical and mental health and their teaching skills. This continuous negative impact of stress on teachers should be addressed and take preventive actions against stress to enhance students' and teachers' academic power.

Gratitude has a positive relationship with job stress. Thus, we try to construct a smooth theoretical framework 
for our research. The main utmost focus of our research is to investigate the effectiveness of gratitude to improve the mental health of school teachers in District Narowal. As shown in the proposed framework model, the researcher will study the relationship between gratitude and job stress. Thus, this has become a new topic and is an exciting topic for us to study deeply.

The workplace environment is essential in organizations, but teachers are the backbone of every society. If all facilities are available to teachers, they are significantly less in the number who uses gratitude weapons efficiently. Instead of using gratitude, they use other ways to cope with their stress, such as watching television. This study's primary aim is to let the primary teacher know the use of gratitude to cope with their job stress. Researchers explicitly evaluated the implementation of a brief gratitude intervention in this context in the present analysis. Gratitude exercises have been done for them to alleviate school teachers ' work stress. There has also been evidence from many studies that there is a correlation between gratitude and stress (Deutsch, 1984; Krause, $2006 \&$ Wood et al. 2008). These variables were assessed by the current study to isolate the impact of gratitude on stress.

The secondary goal of the study was to advance the study on interventions of gratitude. Many of the current studies have some shortcomings, such as undermining their inference, that the assessed effects have a causal effect on this inducing gratitude. The addition of a proper comparison group is probably the most productive way. Almost half of them did not have a monitoring group when they went into gratitude strategies. It leads to uncertainty as to whether the intervention was productive because of praise, anticipation, or simply because it was more fun than the task of comparison.

Understanding the power of gratitude and its positive effects on a person's life has become the backbone of current research. Positive psychology plays an essential role in human behavior to uplift the quality of individual life. Gratitude is one of the robust dimensions of positive psychology that strengthens a person's character, which ancient scholars first use for a person (Peterson \& Seligman, 2004).

Gratitude is recognized as a desirable virtue that can enhance a person's well-being (Watkins, Woodward, Stone, \&Kolts, 2003). Gratitude is one of the powerful weapons which have a lot of positive aspects in life that is

- Increase in-person happiness and satisfaction of life,

- $\quad$ give the strength to fight against threatening situation positively,

- increase the connectivity with other individuals in society,

- $\quad$ improve the present condition of health, and

- $\quad$ enhance the moral dimensions (Worthen\& Isakson, 2007).

Gratitude can never be done on its own it can only be beneficial when induced in a person with proper gratitude training. Most of the training pieces used in the gratitude program are taken from positive psychology that is linked together for the well-being of a person; these exercises require careful examination.

Positive psychology comprises five parts (PERMA): positive emotion, commitment, relationship, meaning, and accomplishment (Seligman, 2011). Gratitude involves "thankfulness of all those good things which a person has in his life and takes some time to speaks positively and express his word of thanks" (Park; Peterson, \& Seligman, 2004). Emmons (2007) explains some assumptions of gratitude:

1. One has been getting a reward from others' kindness.

2. Someone provides benefits voluntarily; it may be some personal.

3. This kindness means a lot to the subject" (Emmons, 2007).

Thus, gratitude always has positive feelings about the external environment (Watts, Dutton, \&Gulliford, 2006). Gratitude can also be grateful in a sense when one's benefit participates a lot in the opponent partner, which gives the appreciation of pleasure. (Watkins, Woodward, Stone, \& Kolts,2003). Several researchers have noted that gratitude can be experienced as an emotion (Bono \&McCollough, 2006; Watkins, Grimm, \&Kolts, 2004; Watkins, Scheer, Ovnicek, \&Kolts, 2006; Watts, Dutton, \&Gulliford, 2006). When we talk about gratitude, it has an intense chain of information with facts that provide linkage to history whose focus is on gratefulness of life (Emmons \&Crumpler, 2000).

Gratitude has several sources through which we can experience gratitude. Wood and colleagues $(2010 ; 2008)$ total number were eight 1 ) individual variations in the perception of thankful influence, 2) other people's appreciation, 3) an emphasis on what the individual has, 4) feelings of awe, 5) acts to express gratitude, 6) concentrating on the good at the present moment, 7) a short perception of life is increasing appreciation, and (8) favorable social comparisons.

These eight factors can be significant aspects of a high level of gratitude experienced at the state of mind and personality trait level (Wood et al. 2008). Gratitude plays an essential role in the education field because Pakistan is a developing country. Due to this, teachers are facing minor and significant stressors related to their jobs. In that circumstance, gratitude can give the power to see the positive picture of any stressor more than a negative one. The economic growth of any country is directly related to education. The central pillar of education is the teacher whose basic aim is to change the child to a reasonably educated person. Students are the one might be the future president, prime minister, or a revolutionary leader. 
Stress is defined as when the person's pressure reaches an extreme level, and then stress will emerge (diFate, 2008). Nowadays, teachers are under a tremendous amount of stress in their respective job because they are responsible for all their families' requirements. All professional teaching is the one in which teachers face a lot of stress compared to other professions (McCarthy, 2009). According to recent work done by Shirley and Kathy (2002) and Kyriacou (1989), their studies proved that one of the stressful jobs is teaching. There are many reasons which make a stressful teacher; one of them is role overloaded, and the other is an increase in class size (Billehoj, 2007).

Many research pieces have found that when a new teacher is appointed in the education department, he has to face a lot of stress so that he wishes to discontinue or change their profession in the first five years. The main reason behind this is job stress, which directly affects his behavior and health (Troman, 1998). When they talk to teachers, they came to know that there would be four out of five headteachers reported burnout in their forties due to high pressure and job workload from higher authorities.

A study was conducted to investigate the impact of gratitude effectiveness in an intervention program to improve the quality of life and reduce the burnout symptoms. The sample consisted of 63 Hong Kong teachers of chines school; their age range was 22-54 voluntary participation in the study. Pre/ post design was used that comprised on to count your blessing for 8 weeks. Results depicted that there was an increase in life satisfaction as well as a significant change in personal accomplishment. In the post-intervention assessment, it was observed that there was a significant decrease in emotional exhaustion and depersonalization. Due to intervention that interacts with the meaningful-life orientation to happiness, substantial improvements have been identified in life satisfaction and emotional fatigue. These reforms favored teachers who placed a higher emphasis on the orientation of meaningful life, indicating that fostering a meaningful orientation of life may be a key element in attempts to engage in gratitude. The results' implications are explored in the creation of gratitude intervention initiatives focusing on human positives and encouraging gratitude and meaningful life orientation in the battle against teacher burnout (chan, 2011)

\section{METHODS}

The Sample size consists of 200 secondary school male teachers working in Sialkot and Multan District. A simple random sampling technique was used for the study. Three instruments were used in the study. A demographic form consisted of personal, academic, and economic information for checking the participant's inclusion criteria. The demographic form included; name, age, gender, education, marital status, number of siblings, living area, socio-economic status.

\section{The Gratitude Questionnaire}

The GQ-6 is a short, self report measure of the disposition to experience gratitude. Participants answer six items on a 1-7 scale ( $1=$ "strongly disagree," and $7=$ strongly agree"). Two items are reverse- scored to inhabit response bias. The GQ-6 is positively related to optimism, life satisfaction. Hope, spirituality and religiousness, empathy and pro-social behavior, and negatively related depression, anxiety, materialism, and envy. The GQ-6 takes less than 5 minutes to complete, but there is no time limit. Cronbach's alpha estimates for the six-item totals have ranged from .76 to .84 . Scores on the GQ-6 correlate substantially with other measures hypothesized to assess how people experience gratitude in daily life.

\section{Job stress scale}

The job stress scale was developed based on the theory of Alves et al. (2004). It is useful in increasing your sense of control in the work setting. Increased feelings of control can improve job-related symptoms of guilt, depression, anxiety, and low self-esteem. Job stress management can also reduce job-related psychosomatic symptoms such as insomnia, ulcers, headaches, eating disorders, and lowered immunity to infection. Job stress inventory consists of 20 items with reliably as Cronbach's alpha of 0.765 .

\section{Procedure}

The study is designed to evaluate the normalizing importance of demographics, gratitude, and job stress. The researchers briefly explained the study before starting the test. There will be a total of 10 sessions, one session per week. The screening was done using a job stress scale, which gave us stress levels; teachers with a high level of job stress were included in the research.

The participants were informed about the nature and purpose of the research and ensured privacy regarding their identity. The study included three phases; the first phase, the Simple Random sampling technique, which has used 200 teachers for the initial sample. This step aimed to screen out the teachers with a high level of stress in the second phase to collect data for the sources, and Job stress scale was applied. 


\section{Statistical Analysis}

To interpret the neural data network was applied. All statistical computation was done through a statistical package for social sciences (SPSS, V-21.0).

\section{Results}

Table 1: Frequencies of Demographic Characteristics of the Sample $(\mathrm{N}=200)$

\begin{tabular}{|c|c|c|}
\hline Characteristics & Frequencies & Percentages \\
\hline & $\mathbf{F}$ & $\%$ \\
\hline \multicolumn{3}{|l|}{ Religion } \\
\hline Muslim & 154 & $97.5 \%$ \\
\hline Non Muslim & 4 & $2.5 \%$ \\
\hline $\begin{array}{l}\text { Job Stress } \\
\text { Normal } \\
\text { Suffering } \\
\text { Need to take preventive action } \\
\text { Age }\end{array}$ & $\begin{array}{l}68 \\
57 \\
33\end{array}$ & $\begin{array}{l}43.0 \% \\
36.1 \\
20.9 \%\end{array}$ \\
\hline $20-25$ & 25 & $15.8 \%$ \\
\hline $26-30$ & 67 & $42.4 \%$ \\
\hline $31-35$ & 40 & $25.3 \%$ \\
\hline $36-45$ & 20 & $12.7 \%$ \\
\hline $46-60$ & 6 & $3.8 \%$ \\
\hline \multicolumn{3}{|l|}{ Education } \\
\hline F.A & 9 & $5.7 \%$ \\
\hline B.A & 43 & $27.2 \%$ \\
\hline M.A & 106 & $67.1 \%$ \\
\hline \multicolumn{3}{|l|}{ Current Pay Scale } \\
\hline 14 & 126 & $79.7 \%$ \\
\hline 15 & 27 & $17.1 \%$ \\
\hline 16 & 5 & $3.2 \%$ \\
\hline \multicolumn{3}{|l|}{ Area } \\
\hline City & Rural & 99 \\
\hline Village & Urban & 59 \\
\hline
\end{tabular}

Table 5.1 shows the Frequencies of different Demographic Characteristics of the sample.

Table 2

Case Processing Summary

\begin{tabular}{|ll|l|l|}
\hline & N & Percent \\
\hline Sample & Training & 8 & $72.7 \%$ \\
& Testing & 3 & $27.3 \%$ \\
Valid & 11 & $100.0 \%$ \\
Excluded & 147 & \\
Total & 158 & \\
\hline
\end{tabular}


Table 3

Network Information of the Variables

\begin{tabular}{|lll|l|}
\hline & Factors & 1 & Recuitment_year \\
Input Layer & Covariates & 2 & Job_Status \\
& Number of Units & \\
& Rescaling Method for Covariates & 5 \\
& Number of Hidden Layers & Standardized \\
Hidden Layer(s) & Number of Units in Hidden Layer 1 ${ }^{\mathrm{a}}$ & 1 \\
& Activation Function & 2 \\
& Dependent Variables 1 & Hyperbolic tangent \\
& Number of Units & sum2 \\
& Rescaling Method for Scale Dependents & 1 \\
Output Layer & Activation Function & Standardized \\
& Error Function & Identity \\
& Sum of Squares \\
\hline
\end{tabular}

A. Excluding the bias unit

Figure 1

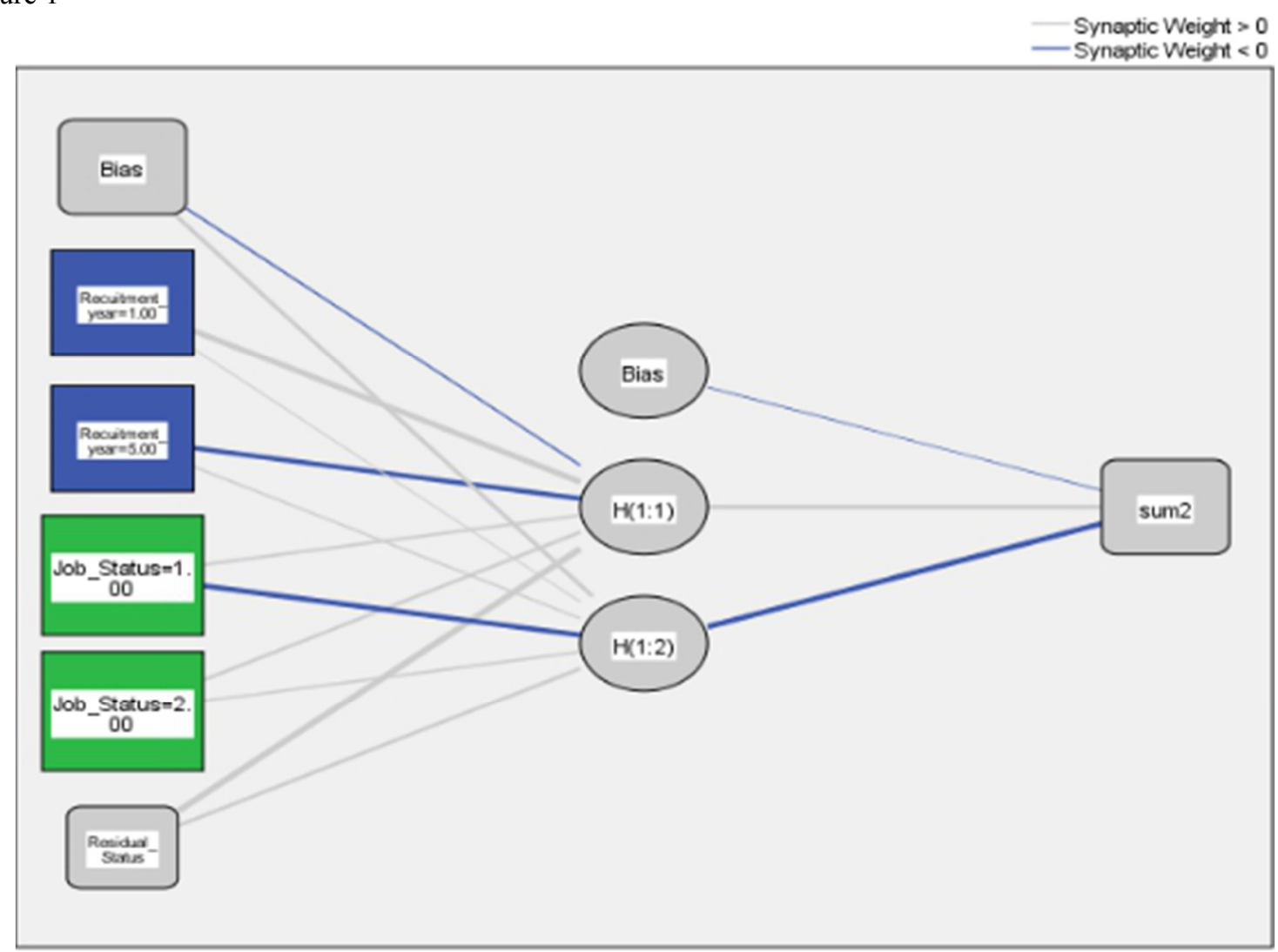

Hidden layer activation function: Hyperbolic tangent

Output layer activation function: Identity 
Table 4

Model Summary of Varibales

\begin{tabular}{|ll|l|}
\hline \multirow{4}{*}{ Training } & Sum of Squares Error & 3.563 \\
& Relative Error & 1.018 \\
& Stopping Rule Used & 1 consecutive step(s) with no decrease in error ${ }^{\mathrm{a}}$ \\
& Training Time & $0: 00: 00.00$ \\
\multirow{2}{*}{ Testing } & Sum of Squares Error & .899 \\
& Relative Error & 1.087 \\
\hline
\end{tabular}

Dependent Variable: sum2

A. Error computations are based on the testing sample.

Table 5

Independent Variable Importance

\begin{tabular}{|l|l|l|}
\hline & Importance & Normalized Importance \\
\hline Recuitment_year & .365 & $71.7 \%$ \\
Job_Status & .509 & $100.0 \%$ \\
Residual_Status & .125 & $24.6 \%$ \\
\hline
\end{tabular}

The neural network model gives information about the importance of prediction of demographic factors for role of gratitude and stress.

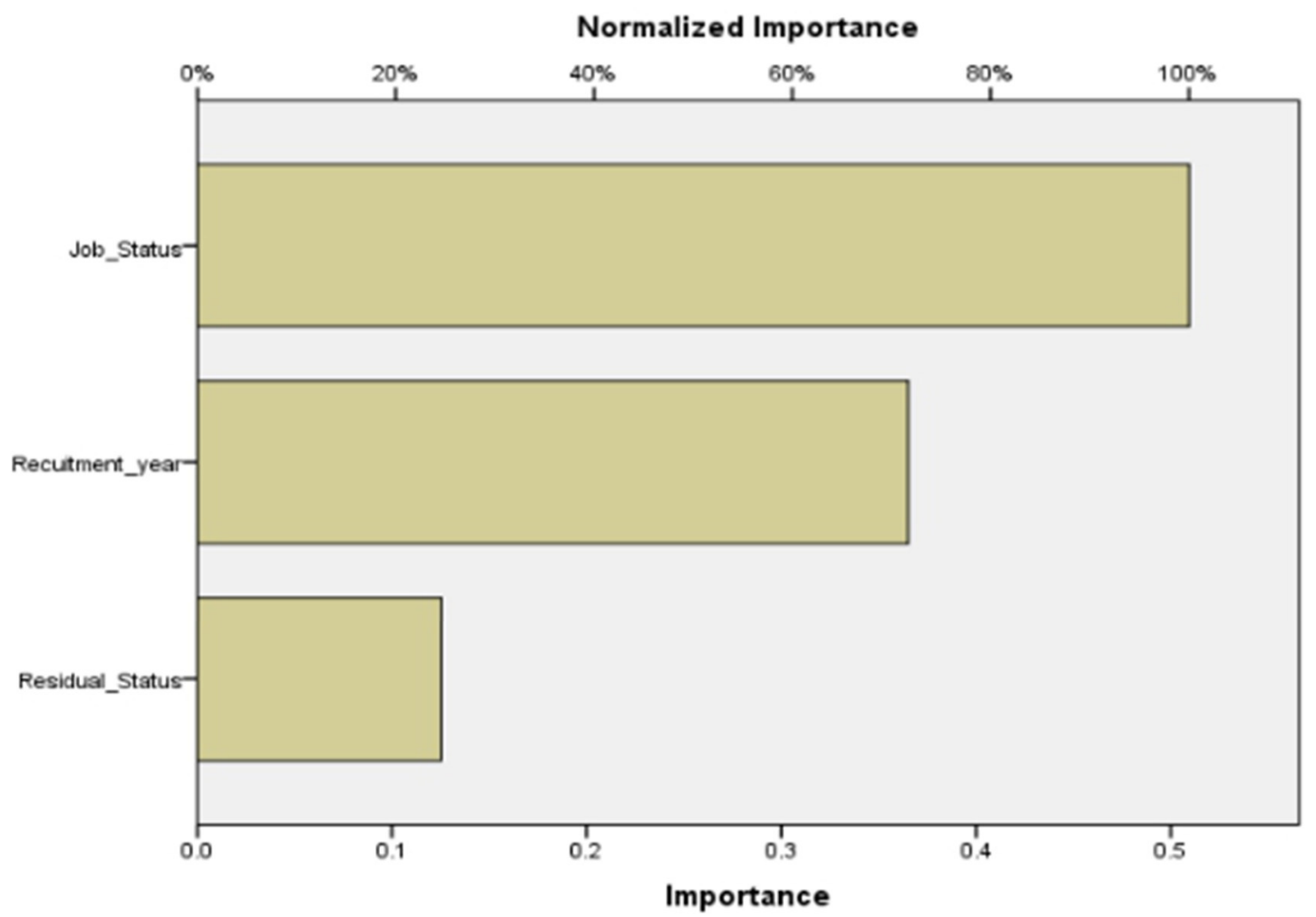

Consequently, a transparent neural network model seemed that explained the importance of independent variables for the role of gratitude and stress. The chart of importance shows that the results were dominated by job status, recruitment year, and residual status.

\section{Conclusion}

As depicted in table 2, training for the cross entropy error was equal to 74.333 (a sample size at 127 with $67.2 \%$ sample size), and in testing, cross entropy error was 31.400 with (a sample size at 62 with $32.8 \%$ sample size). The percent incorrect predictions of the training set were $21.3 \%$, whereas the percentage was $21.0 \%$ in testing. If the percent incorrect predictions are constant in training and testing, it gives them confidence about the correct 
model. In the case of current research, the difference is minimal for training and testing.

As depicted in table 4, training for the cross entropy error was equal to 1.018 (a sample size at 8 with $72.7 \%$ sample size), and in testing, cross entropy error was 1.087 with (a sample size at 3 with $27.3 \%$ sample size). The percent incorrect training and testing set predictions are constant; it gives them confidence about the model as correct.

The result indicated in table 5 that the most critical predictor of the role of gratitude and stress was job status 0.509 (100\% normalized importance) next was recruitment year 0.365 (71.7\% normalized importance) and residual status 0.125 (24.6\% normalized importance). The importance can be seen in Figure 1

Consequently, a transparent neural network model seemed that explained the importance of independent variables for the role of gratitude and stress. The chart of importance shows that the results were dominated by job status, recruitment year, and residual status.

\section{REFERENCES}

Armenta, C. N., M. Fritz \& S. Lyubomirsky, (2016). Functions of positive emotions: Gratitude as a motivator of self-improvement and positive change. Emotion Review, 9(3), 183-190.

Bono, G. \& Mccullough, M., E., (2006). Positive Responses to Benefit and Harm: Bringing Forgiveness and Gratitude. Journal of Cognitive Psychotherapy, 20(2),147-158

McCullough, M. E., Emmons, R. A., \& Tsang, J. A. (2002). The grateful disposition: A conceptual and empirical topography. Journal of Personality and Social Psychology, 82(2), 112-127.

Emmons, R. A. \& McCullough, M. E., (2003). Counting blessings versus burdens: An experimental investigation of gratitude and subjective well-being in daily life. Journal of Personality and Social Psychology, 84(2), 377389.

Chan, D. W. (2011). Burnout and Life Satisfaction: Does Gratitude Intervention Make a Difference among Chinese School Teachers in Hong Kong? Journal of Educational Psychology, 31(7), 1-15

Diener, Ed. (1999). SubjrctiveWell-Being:ThreeDecages of Progress. Psychological Bulletin, 125 (2), $276-302$. doi: 10.1037/0033-2909.125.2.276

Diener, E., \& Lucas, R. E. (1999). Personality and subjective well-being. In D. Kahneman, E. Diener, \& N. Schwarz (Eds.), Well-being: The foundations of hedonic psychology(pp. 213-229). New York: Russell Sage Foundation.

Diener, E., \& Chan, M. Y. (2011). Happy people live longer: Subjective well-being contributes to health and longevity. Applied Psychology: Health and Well-Being, 3, 1-43.

Lyubomirsky, S. (2013). How do simple positive activities increase well being.Current direction in psychological science,22(1), 570062. doi: 10.1177/0963721412469809

Fredrickson, B. L. (2013, July 15). Updated Thinking on Positivity Ratios. American Psychologist. Advance online publication. doi: 10.1037/a0033584

Snyder, C. (1996). Development and validation of the state hope scale. Journal of personality and social psychology, 70 (2), 321-326.doi: 10.1037/0022-3514.70.2.321

Sauter, S. L., Murphy, L. R., \& Hurrell, J. J. (1992). Prevention of work-related psychological disorders: A national strategy proposed by the National Institute for Occupational Safety and Health (NIOSH). In G. P. Keita \& S. L. Sauter (Eds.), Work and well-being: An agenda for the 1990s (p. 17-40). American Psychological Association.

Scott, W. E. (1966). Activation theory and task design. OrganizationalBehavior and Human Performance, 1, 3-30

Wilkes, L., Beale, B., Hall, E., Rees, E., Watts, B., \& Denne, C. 1998. “Community nurses' descriptions of stress when caring in the home", International Journal of Palliative Nursing, 4 (1).

Alexandros-Stamatios G. A., Matilyn J.D., and Cary L.C., 2003. "Occupational Stress, Job satisfaction, and health state in male and female junior hospital doctors in Greece", Journal of Managerial Psychology, 18(6), pp. $592-621$

Gaillard, A.W.K. (1988) 'The evaluation of drug effects in laboratory tasks'. In: Hindmarch, I., Aufdembrinke, B. \& Ott, H. (Eds.), Reaction time and drug effects. New York, Academic Press.

Sanders, A.F. (1983) 'Towards a model of stress and human performance'. Acta Psychologica. 53, 61-97.

Rehman, Muttieur, RabbiaIrum, NamraTahir, Zara Ijaz, Uzma Noor, Ume Salma, (2012).“The Impact of Job Stress on Employee Job Satisfaction: A Study on Private Colleges of Pakistan", Journal of Business Studies Quarterly, Vol.3, No.3, pp.50-56

Mansoor, M., Fida, S., Nasir, S. and Ahmad, Z. (2011) The Impact of Job Stress on Employee Job Satisfaction: A Study on Telecommunication Sector of Pakistan. Journal of Business Studies Quarterly, 2, 50-56.

Cohen S, Miller GE, Rabin BS. Psychological stress and antibody response to immunization: A critical review of the human literature. Psychosomatic Medicine. 2001;63:7-18.

Dhabhar FS, McEwen BS. Acute stress enhances while chronic stress suppresses cell-mediated immunity in vivo: A potential role for leukocyte trafficking. Brain, Behavior, and Immunity. 1997;11:286-306. 
Kiecolt-Glaser JK, Glaser R, Gravenstein S, Malarkey WB, Sheridan J. Chronic stress alters the immune response to influenza virus vaccine in older adults. Proceedings of the National Academy of Sciences, USA. 1996;93:3043-3047.

Deutsch, C. J. (1984). Self-reported sources of stress among psychotherapists. Professional Psychology: Research and Practice, 15(6), 833.http://dx.doi.org/10.1037/0735-7028.15.6.833

Krause, N. (2006). Gratitude toward God, stress, and health in late life. Research on Aging, 28(2), 163-183.

Wood, A. M., Maltby, J., Gillett, R., Linley, P. A., \& Joseph, S. (2008). The role of gratitude in the development of social support, stress, and depression: Two longitudinal studies. Journal of Research in Personality, 42(4), 854- 871.https://doi.org/10.1016/j.jrp.2007.11.003

Peterson, C., \& Seligman, M. E. P. (2004). Character strengths and virtues: A handbook and classification. American Psychological Association; Oxford University Press.

Watkins, P. C., Woodward, K., Stone, T., \& Kolts, R. L. (2003). Gratitude and happiness Development of a measure of gratitude, and relationships with subjective well-being. Social Behaviour and Personality, 31, 431-451.

Worthen, V. E., \& Isakson, R. L. (2007). Therapeutic value of experiencing and expressing gratitude. Issues in Religion and Psychotherapy, 31, 33-46.

Peterson, C., \& Seligman, M. E. P. (2004). Character strengths and virtues: A handbook for classification. Washington, DC: American Psychological Association

Park ,Mansook. (2004). Strength of character and well being.Journal of social and clinical psychology, 23 (5), 614-624.

Seligman, P. (2007). Strength of character, orientation to happiness, and life satisfaction.Journal of positive psychology, 2 (3), 149-155.doi: 10.1080/17439760701228938

Emmons, R. A. (2007). Thanks! How the new science of gratitude can make you happier New York: Houghton Mifflin Company.

Watts, F., Dutton,k.,Gulliford,L.,(2006). Human spiritual qualities: Integrating psychology and religion. journalofMental Health, Religion and Culture, 9(3), 277-289

Watkins, P. C., Woodward, K., Stone, T., \& Kolts, R. L. (2003). Gratitude and happiness Development of a measure of gratitude, and relationships with subjective well-being. Social Behaviour and Personality, 31, 431-451.

Watkins, P. C., Grimm, D. L., \& Kolts, R. (2004). Counting your blessings: Positive memories among grateful persons. Current Psychology, 23, 52-67.

Watkins, P., Scheer, J., Ovnicek, M., \& Kolts, R. (2006). The debt of gratitude: Dissociating gratitude and indebtedness. Cognition and Emotion, 20, 217-241.

Emmons, R. A., \& Crumpler, C. A. (2000). Gratitude as a human strength: Appraising the evidence. Journal of Social and Clinical Psychology, 19, 56-69.

McCarthy, R. (2009). Protecting the perineum: we been duped by HOOP? British Journal of Midwifery, 17(12), 779-781.

Shirley, L. K., \& Kathy, M. H. (2002). Stress Hormones: How Do They Measure Up? Biological Research for Nursing, 4, (2): 92-103.

Kyriacou, C. (1989). The Nature and Prevalence of Teacher Stress. In Jennifer, L. M., Ralph, O. M., and Dean L.

M. (1991). The Effects of Teaching Experience and Grade Level Taught on Teacher Stress: A Lisrel Analysis. Teaching and Teacher Education. 7, 57-62.

Billehoj, H. (2007). Report on the ETUCE Survey on Teachers' Work-related Stress.

Troman, T. (1998). Teachers' work/stress. Living at a hundred miles an hour: primary teachers' perceptions of work and stress. Paper presented at the British Educational Research Association Annual Conference, Queen's University of Belfast, Northern Ireland, August 27th to August 30th 1998. 